\title{
Let It Pass: Changing the Subject, Once Again
}

\author{
Pamela L. Caughie \\ Loyola University Chicago, pcaughi@luc.edu
}

Follow this and additional works at: https://ecommons.luc.edu/english_facpubs

Part of the English Language and Literature Commons

\section{Recommended Citation}

Caughie, PL. "Let It Pass: Changing the Subject, Once Again." PMLA 112(1), 1997.

This Article is brought to you for free and open access by the Faculty Publications and Other Works by Department at Loyola eCommons. It has been accepted for inclusion in English: Faculty Publications and Other Works by an authorized administrator of Loyola eCommons. For more information, please contact ecommons@luc.edu.

\section{(c) (i) $९$}

This work is licensed under a Creative Commons Attribution-Noncommercial-No Derivative Works 3.0 License. (c) Modern Language Association, 1997. 


\section{Let It Pass: Changing the Subject, Once Again}

PAMELA L. CAUGHIE teaches twentieth-century literature and theory at Loyola University, Chicago. She is author of Virginia Woolf and Postmodernism ( $U$ of Illinois $P, 1991)$ and is completing the manuscript of a book, Passing and Pedagogy: The Dynamics of Responsibility ( $U$ of Illinois $P$ ), which includes a version of this essay. Another version of the essay will appear in In Other Words: Feminism and Composition Studies, edited by Susan C. Jarratt and Lynn Worsham (MLA, forthcoming).
Unlike the stereotypical feminist model that suggests women best come to voice in an atmosphere of safety . . ., I encourage students to work . . . in an atmosphere where they may be afraid or see themselves at risk.

bell hooks, Talking Back

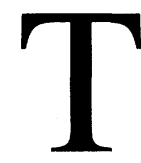

HIS ESSAY attempts to intervene theoretically and pragmatically at a critical moment in our profession, when literary studies in colleges and universities across the United States is increasingly becoming culture studies.' This transformation over the past two decades in the social, philosophical, and political bases of the humanities is due partly to the academy's efforts to acknowledge diversity, by institutionalizing multiculturalism and various "studies programs" (women's studies, gay studies, ethnic studies, composition studies) in response to the influx of nontraditional students since the early 1970s, and partly to poststructuralism's efforts to theorize difference and to destabilize the very categories of identity on which those studies programs are founded. Such programs, particularly women's studies, have traditionally been devoted to a humanist concept of the subject as "source and agent of conscious action or meaning" (P. Smith xxxiii-xxxiv) and committed to opening this subject position to previously marginalized groups. In contrast, poststructuralist theories, including some feminist theories, have revealed the humanist subject to be a sham insofar as it is the effect, not the origin, of representation. As this essay suggests, when antifoundational theories that deconstruct the self converge with studies programs that revive it, anxiety arises over the positions we find ourselves in as scholars and teachers in the newly configured university. ${ }^{2}$

Culture studies would seem to offer a pedagogy for working through the tensions between these two perspectives on the subject since issues of identity formation and of subject position are central not only to its object of study but to its method of inquiry. Culture studies has shifted 
the focus of literary studies from interpreting, transmitting, or preserving individual texts considered representative of particular cultures to analyzing culture as a historically specific ensemble of social practices and signifying systems that provide, in Mary Poovey's words, "the terms through which humans understand our world [and] from which we derive our identity" ("Criticism" 618). Given that the reading, writing, and teaching we do as academics partially constitute the cultural formations it seeks to interrogate, culture studies necessarily takes the work of teachers and scholars as one of its objects of scrutiny. Concerned with "the complex ways in which identity itself is articulated, experienced, and deployed" (Nelson, Treichler, and Grossberg 9) and with the "politics of location" (Faigley 218), culture studies requires its practitioners "to include in their critical view the conditions of their own existence" at the same time that it identifies itself "polemically with certain social constituencies"-for instance, blacks, women, workers (Bathrick 323-25). The classroom becomes a site of both cultural intervention and continual self-critique. To practice culture studies, as Susan Rubin Suleiman writes in another context, "is to implicate yourself, your self, in what you write" (2) and what you teach.

Yet however strong, however sincere, our commitment as literature professors to certain social constituencies and to continual self-critique, when ethnicity becomes "the new frontier, accessible to all" (hooks, Yearning 52), when men become feminists and straights become queer, when African American studies and women's studies become cultural studies, when a prominent feminist can write, "I began to wonder whether there was any position from which a white middle-class feminist could say anything on the subject [of race] without sounding exactly like [a white middle-class feminist].... In which case it might be better not to say anything" (Miller, "Criticizing" 364)—something, it seems, has gone wrong. The practitioners of culture studies experience a double bind in which the desireindeed, the imperative-to speak as or for members of a particular social group conflicts with the anxieties such a practice evokes. The writer who deliberately assumes another's position risks being accused of unconsciously doing so. ${ }^{3}$
In recent writings, I have deployed the term passing to describe our subject positions in postmodern culture and by extension in a culture studies paradigm. ${ }^{4}$ Passing traditionally refers to the practice of representing oneself-for social, economic, or political reasons - as a member of a particular group not considered one's own. Historically, the practice is mainly, though not exclusively, associated with the assumption of a white identity by light-skinned African Americans. Passing is generally implicated in a racist social organization. The painful psychic consequences of passing attested to in many narratives are corporeally depicted in Agnieszka Holland's 1991 film Europa, Europa, based on Solomon Perel's autobiography, in which the protagonist, a German Jew, tries to conceal his identity from his Nazi companions by pulling what remains of his foreskin over the tip of his penis and tying it in place with a piece of thread.

In its traditional sense, passing often carries pejorative connotations of deception, dishonesty, and betrayal. ${ }^{5}$ When used as a metaphor, with the operative $a s$, the term can apply to situations in which one engages in impersonation for the purpose of fraud. But in my use, passing (without the as) figures the always slippery difference between standing for something (having a firm position) and passing as something (having no position or a fraudulent one), between the strategic adoption of a politically empowered identity (e.g., when blacks pass as white) and the disempowering appropriation of a potentially threatening difference (e.g., when men pass as feminist), and between what one professes as a teacher (the positions one assumes in the classroom, often speaking for another) and how one is positioned in a society, an institution, a discourse, or a classroom. Marking a discrepancy between what one professes to be (and what one professes, as a writer or teacher) and how one is positioned, passing is risky business-but, as this essay professes, unavoidable. For there is no occupying a position without passing. Thus I offer passing not as a solution to the double bind I outlined above but as a descriptive theory of its dynamics.

Unlike the more common notions of speaking as and speaking for, passing disrupts subject positions. The difference between these two ways of conceptualizing the problem is highlighted by two 
sentences that appear on the same page of Linda Alcoff's "The Problem of Speaking for Others," which analyzes many of the issues and impasses I confront in this essay. For Alcoff, the problem of speaking for arises from the recognition that the "positionality" of the speaker "bears on" the meaning and truth of what the speaker says (an insight that women's studies and African American studies programs were founded on) and that some privileged locations are "discursively dangerous" no matter what the speaker's intentions (6-7). ${ }^{6}$ Realizing the dangers but opposing a retreat from the practice of speaking for, Alcoff offers imperatives for ensuring that speakers' representations of others are responsible. The primary injunction is that speakers must interrogate the effects of their social locations on what they say (24-26).

Alcoff's insistence on self-critique combines a materialist focus on specific locations with a postmodernist understanding of the discursive character of subjectivity. The "mediated character of all representations" (9) is acknowledged in the two sentences I want to compare:

When I speak for myself, I am constructing a possible self, a way to be in the world, and am offering that to others, whether I intend to or not, as one possible way to be.

When I "speak for myself" I am participating in the creation and reproduction of discourses through which my own and other selves are constituted.

Alcoff seems to be saying much the same thing in these two sentences, yet the quotation marks around "speak for myself" in the second make the (dia)critical difference. In the first sentence, the I takes for granted that it can speak for itself, that it can occupy a subject position, that there even are subject positions one can occupy, however selfconsciously. In the second sentence, the I is performative, constituted in and through speaking, the act of invoking an I. The second sentence reveals the I of the first and the subject of Alcoff's imperatives to be a seduction of grammar (Butler, Bodies 6). The one who writes the first sentence forgets the I of the second, writing as if one could be immune to the effects of performance. ${ }^{?}$
The impasse between Alcoff's two sentences gives rise to the structural dynamics that I term passing. The slippage between the volitional and the performative subject makes passing inevitable whenever any I claims to speak for itself. ${ }^{8}$ Even if as teachers and critics of culture studies we acknowledge our social locations as multiple and unstable, shaped by specific histories and subject to various representational technologies, we always talk of subject positions and self-critique as if we were immune to performance and thereby resuscitate in practice (in grammar) the subject we dismantle in theory. In this sense, as Mas'ud Zavarzadeh and Donald Morton argue (15-16), the practice of writing itself may resist the radical insights of postmodern theories, putting us all in the position of passing when we speak for ourselves and others. Passing is neither something one does (as in performing a role) nor something one is (a subject position we must account for) but a way of naming and conceptualizing an interpersonal, psychopolitical dynamics that for many of us structures the experience of reading, teaching, and writing about literature today. ${ }^{9}$ Passing is not always and only a volitional act that an already positioned subject chooses to engage in. Passing happens, and it happens despite, or more often because of, our sincere efforts to get it right. ${ }^{10}$

In this essay, I engage performatively with cultural and pedagogical debates over the nature of the subject by working through the dynamics of passing exemplified in a particular exchange on this issue among feminists, in two student responses to the 1934 film Imitation of Life, and in Fannie Hurst's novel that inspired the film. My purpose is not only to argue for a performative concept of the I but also, and more important, to show that taking a certain position on the subject-whether as feminists, cultural critics, or literature teachers-is not the same as accepting responsibility for the subject positions we assume and put into play in the classroom.

\section{The Subject in Feminism}

The question of women as the subject of feminism raises the possibility that there may not be a subject who stands "before" the law, awaiting representation in or by the law. Judith Butler, Gender Trouble 
Two prominent debates among feminists in the 1990s have centered on the viability of postmodern theories for feminist politics and on the political implications of the use white feminists make, in their writing and teaching, of black women's texts. These debates are not unrelated, since black and white feminists alike have accused some white feminists of exploiting the "fractured public identities" (Berlant 121) of African American women to promote a new postmodern subjectivity. Whereas twenty years ago white feminists were accused (fairly) of ignoring black women's writings and experiences in their theories, today they are accused of turning to black women's writings and bodies to rereferentialize or rematerialize an increasingly abstract and disengaged theoretical feminism. Twenty years ago, before the institution of culture studies in the United States academy, one of two mutually exclusive responses to these charges of neglect prevailed: to add the particular oppressions faced by black women to a universal and liberationist theory of gender oppression or to admit, as Patricia Meyer Spacks did in The Female Imagination, that a white middle-class woman could not theorize about experiences she had not had (see Carby, ch. 1). In contrast, contemporary cultural critics, who problematize the very boundaries of social identities on which such responses rested, are more likely to attend to "the operations of race in the feminine" (Abel 471). Today we hear less about the failure of the (white) female imagination to project itself into unfamiliar experiences than about the exposure of white (female) desires in that very effort-to speak as or for black women.

Two recent articles by white feminist critics demonstrate not only the requirement of culture studies that we speak on behalf of certain social constituencies while engaging in self-critique but also the double bind created by this imperative. Margaret Homans in "'Women of Color' Writers and Feminist Theory" and Elizabeth Abel in "Black Writing, White Reading: Race and the Politics of Feminist Interpretation" critique white feminists' use of black women's texts and are, to differing degrees, selfconscious, indeed nervous, about the double bind of their own positions as white feminist critics writing on black women's texts. Together these essays provide a pretext for analyzing the dynamics of passing in cultural criticism and critical pedagogy. ${ }^{11}$

Homans criticizes certain feminists (Diana Fuss, Donna Haraway, and Judith Butler) for appropriating texts by "women of color" (Homans's term) to figure a postmodern theory of subjectivity that critiques "bodily or biological based theories of gender" and identity (82). Citing only the "postmodern" aspects of the texts they appropriate, these theorists, Homans charges, downplay the texts' ambivalence. They ignore that the works in fact position themselves on both sides of the identity debate, invoking a natural or already existing identity and revealing an awareness that such an identity is always "in the process of being made" (79). Homans revalues these texts' naturalizing tendencies, the ways in which "women of color" reclaim themselves as embodied subjects. The texts promote a concept of identity as embodiment: they construct the black female body as natural (86). To use these texts as examples of postmodern theories of the subject, which for Homans are theories of disembodiment, is to deny the texts' claim to the natural while reembodying theories of dis-embodiment, making "women of color" do the cultural work they have always donenamely, embodying the body for white culture (73).

As an example, Homans contrasts treatments of Sojourner Truth by Donna Haraway and Alice Walker. Haraway urges us to be like Sojourner Truth, who becomes in her essay a figure for a "nongeneric, nonoriginal humanity" (qtd. in Homans 78). For Haraway, Homans says, the body of the black woman is a "resource for metaphor" (77). Walker, in contrast, achieves a "personal identification" with Sojourner Truth, claiming to be her. Whereas Haraway's figurative language is "an alibi for dematerializing the [black] female body" (78), Walker's identification is a way of (re)claiming that body. In Homan's reading, Walker and Truth stand before the law (of representation), bearing an unmediated relation to the black female body-embodying it naturally, as if their identity were so close to nature that it did not pass through the filter of cultural discourses, those "powerful institutionalized rhetorics that provide the terms in which to represent the self as a subject in relation to others" (Brodkey, "Pedagogy" 138). Yet the ambivalence Homans notices 
in black women's writings would also suggest these writers' recognition of the filter.

Abel's critique of Barbara Johnson follows the same lines as Homans's reading of Haraway and Butler. Johnson ignores in Zora Neale Hurston's writings "a possible belief in, or desire for belief in, a black identity," Abel argues, because Johnson understands race as rhetorical rather than literal (480). For Johnson, representations of a black essence operate within "specific interlocutionary situation[s]" and are "matters of strategy rather than truth" (qtd. in Abel 480). By dereferentializing race, Abel says, Johnson displaces "a discourse on race" with "a discourse on positionality," a move that enables the white deconstructionist to write as the black novelist. By as, Abel means not only "in the manner of" (for she has just compared Johnson's and Hurston's techniques of framing their essays) but also "in the subject position of." For if race is simply a matter of figuration, a white critic can assume the position of a black writer. Drawing on Johnson's critique of male philosophers who position themselves as women, Abel points out that Johnson, while capable of positioning herself philosophically as a black woman, cannot be positioned politically as black. Failing to make this distinction, Johnson risks "dislocating race from historically accreted differences in power" (482-83).

Homans and Abel demonstrate effectively that adopting a certain theoretical position on the subject (in this case, a reputedly postmodernist position) is not the same as taking responsibility for one's own subject position as enacted in one's writing, and to this extent they advance one argument I am making about passing. And both reveal, to recall Abel's phrase, "the operations of race in the feminine." But what interests me are the solutions Homans and Abel present to the problem of writing across racial differences, the ways in which they try to save themselves, as well as (white) feminist criticism, from exposing themselves - that is, from passing in the pejorative sense.

According to Homans, the "cultural problematic" in white feminist writings on black women's texts is both "a problem of race relations in the academy" and part of "the widespread debate over the uses of postmodernist theory for feminist political practice"
(76). The troubling question, as Homans acknowledges, is whether this cultural problematic authorizes or invalidates (or both) her position in her essay. While Homans never explicitly returns to this question, she implies an answer. She comes close to suggesting (as does Nancy Miller in the remark cited above) that white feminists should have nothing to do with-or at least do nothing with-the writing of "women of color." Ironically, since she uses such writing, this argument would put Homans in the position of passing as black. But the difference between Homans and the feminists she attacks lies not in the fact that they use black women's writings to defend their positions on the subject but in the positions they take. As Abel points out, for Homans all women share the cultural condition of embodiment, which is devalued because the symbolic register (figuration) depends on the exclusion of "the female (maternal) body" (literalness) (484). Thus, it is precisely the construction of the black female body as natural that not only makes Alice Walker's claim to (be) Truth tenable but also enables Homans to represent a theory of embodied subjectivity through Walker while at the same time saving herself from her own criticism of white feminists who use black women to embody their theories. Homans exonerates herself from her racially charged accusations against others by claiming to use black women's figures of embodiment instead of making the women figures for her position on embodiment (which happens to coincide with theirs).

Yet Homans's effort to reclaim or reliteralize the black woman's body, as she questions "the political utility of arguments that dissociate feminism from the body" (87), does not save her from charges of appropriation but implicates her in an instance of passing far more audacious than the examples she cites. Characterizing postmodern feminists as the exploitative white mistress whose work is done by black women, Homans casts herself in the role of the domestic. As she puts it, black women in her essay "are working ... for themselves at least as much as for me. Perhaps it could even be said that I am working for them" (88). The rhetoric of domestic service serves Homans's interests in the same way she claims black women's historically constituted identities serve postmodern feminists' inter- 
ests. The rhetorical gesture allows her to pass not only as the domestic (working for others) but also as a black woman, speaking as and for black women in the pages of New Literary History and in this feminist debate over the subject. In the name of reclaiming embodiment, Homans embodies another's position and then uses that figurative position to attack a theory of figuration. The rhetoric of her assertion is incompatible with its explicit meaning, and her performance (her assumption of an identity) comes into conflict with the identity she would assume (take for granted).

I do not mean to deny the value of Homans's essay, especially in its attention to the writings of black feminist theorists. Rather, my point is that there is in the essay an incompatibility between her rhetoric and her meaning, her performance and her theory. This is, I argue, a function of the dynamics that I have identified as inherent in the cultural problematic that Homans sees as the problem to be resolved. Failing to interrogate how this problematic inflects her writing (the ways in which she may be passing), Homans displaces the general fear that the essence of feminism (not just a shared concept of woman but also the idea that women share the same positions) is at risk in postmodernity with the more specific anxiety that "women of color" are being denied the opportunity to represent themselves because white feminists have unfair access to the means of representing theory in the academy and unfair access to "race" as, in hooks's words, "the new frontier." 12 I do not refute this specific claim, but I question the effort to get out of this structure by reclaiming the body in the name of "women of color."

In calling for "thick descriptions" as a more viable feminist practice (496) and in engaging the writings of feminists of different theoretical persuasions, Abel at least potentially directs her attention to feminist criticism as an institution rather than to a particular kind of feminism. Analyzing the work of Homans, Johnson, and Susan Willis, Abel argues that no matter what theoretical position they take, their readings across racial lines are marked by white desires. Comparing Johnson and Homans, Abel writes that whereas "privileging the figurative enables the white reader [Johnson] to achieve figurative blackness" (to speak as), "privileging the literal enables the white woman reader [Homans] to forge a gender alliance" across race (to speak for) (485). Black and white writers meet in shared figurality for Johnson; black and white women meet in shared literality for Homans. Both feminists, Abel continues, use black women to legitimate their own positions, and for both, race is "a salient source of fantasies and allegiances that shape" white women's reading of black women's writing $(486,497)$. All these efforts to read across racial lines are for Abel forms of passing, and in the end, all passing fails because "our inability to avoid inscribing racially inflected investments and agendas limits white feminism's capacity either to impersonate black feminism, and potentially render it expendable, or to counter its specific credibility" (497). Instead of deflecting these racial investments onto particular feminists, Abel calls for a particular practice among white feminists reading black women's writing: to provide "thick descriptions" of black women's texts and to engage in continual self-critique.

In the opening of her essay, Abel practices selfcritique, embarrassingly exposing her own "racially specific investments" in her reading of Toni Morrison's story "Recitatif." For Abel, self-critique depends on confession, and the confessional I is the guilty I. This I-whether Abel's or Nancy Miller's or Descartes's-responds to the anxiety of finding that the I is not what it thinks (i.e., that it is a fraud) by trying to master the self, hailing us right back to the Enlightenment notion of the subject before the law. The belief that we can and must rid ourselves of unruly desires before we can write responsibly about others is not unlike the desire for an unmarked position that characterizes Enlightenment discourses. Both presuppose the self-determining, rational subject of humanism. Abel's call for an alternative practice for feminist criticism assumes that honest individuals, who are coherent, comprehending subjects, can give an honest account of themselves (see Poovey, "Feminism" 37, 42). For Abel, as for Homans and Miller, the subject in feminism is already there, constituted by her (white) desires and exposing herself at every turn.

In Abel's and Homans's analyses, passing is a charge to level against others, an illegitimate subject position, or a practice to be consciously avoided through persistent self-critique. Isolating the categories of race and gender from other social 
determinants, as both women tend to do, does not invalidate the insights provided by their analyses, but it does mean that neither critic is capable of analyzing the way in which passing originates in the cultural problematic that Homans identifies as a problem of race relations in the academy and as a consequence of postmodern theory and culture. Suffering guilt over prior exclusionary practices and anxiety about the precariousness of identity in postmodern culture, some white feminists seek comfort in confessions that aim to reclaim the subject in the name of those who in part have brought about the crisis of identity in feminism and in the general culture. Indeed, practicing self-critique as confessional seems to intensify white writers' tendency to use blacks "as a way of talking about and policing matters of repression and meditations on ethics and accountability" (Morrison 7). For this reason, Abel, who connects her critical project with Morrison's in Playing in the Dark, cannot avoid participating in the very practice she seeks to expose. Nor can I or anyone else who is similarly positioned in the academy.

Failing to account for the postmodern context of her own analyses, Abel misses the point of her call for thick descriptions of "a cultural economy which constructs the feminine in the domain of racial difference" (Wiegman 323). If white feminists, in Robyn Wiegman's words, tend "to circulate 'racial difference' as a commodity in our own discourses, pasting over the white bourgeois woman who occupies the center of our theoretical paradigms with images of black women whose historical and material specificity we thereby render indecipherable" (as Abel and Homans argue), then "the future of feminism depends on revealing the inadequacies of its most privileged theoretical category"-women (326). This is the task of postmodern feminism, if postmodernism is understood as a historical and cultural imperative and not merely as a theory of identity.

I have discussed this debate over the subject in feminism at some length for two reasons. First, at least insofar as it gives rise to efforts to expose the passer and to a form of self-critique that entails policing identities, this debate can have the effect of making students unwilling to risk themselves in their writing (or, in Suleiman's terms, to risk being contemporary), thereby rendering them incapable of analyzing the import of postmodernism for the multiple subject positions that any person can inhabit and that make up the body politic (see Wicke 30; Harper, Framing 90-91). This debate can make students feel they must get it right, say the right things, make the right moves, and avoid revealing too much of themselves. Yet, contradictorily, what women's studies, African American studies, and composition studies - as responses to the influx of nontraditional students into the academy-have historically sought to do is to allow more exposure of the self in writing. As forms of critical pedagogy, feminism and culture studies must resist efforts to reclaim "a sovereign, self-aware consciousness at the center of the composing act," in practice as much as in theory, by shifting attention from the individual writer to the scene of writing-to the possibilities and constraints of the rhetorical and cultural situation in which we find ourselves (see Crowley $32-34,46$ ). For, and this is my second point, as a politics of positioning (not a new theory of identity but a response to the problem of identity in postmodern culture), passing is an effect of the institutional and cultural realities in which we teach and write. As Amy Robinson argues, "In an academic milieu in which identity and identity politics remain at the forefront of a battle over legitimate critical and/or political acts, the social practice of passing offers a productive framework through which to reimagine the contours of this debate" (716). If culture studies is about nothing else, it is about revealing the ways in which what appears natural, given, is historically and culturally produced. In structuring our writing and reading assignments, we need to seize the opportunities for passing that the emergence of culture studies in the academy has created. Culture studies makes passing unavoidable, perhaps inevitable.

\section{Class Notes: An Interlude}

Women have rarely been composers. But we do have one advantage. We're used to performing.

Laurie Anderson (qtd. in McClary)

In a writing-intensive core course on the Harlem Renaissance, I showed the 1934 film Imitation of 
Life, a melodrama based on a popular novel by Fannie Hurst and remade in 1959, and asked the students to respond in their journals to the relationship between the two mothers in the film, Bea Pullman and her live-in domestic, Delilah. One woman, who asked me not to share her response with the class, clearly expressed the anxieties that arise when a humanist concept of the subject comes into conflict with a critical pedagogy:

I am not even really sure if this is supposed to be an important part of the movie but it got me thinking. It's the "friendship" between Aunt D. and Miss B. The reason I am a bit confused is because I am not sure I am supposed to take it at face value. Here is the way I saw the friendship: I believe it was an honest to goodness one. For example, when Aunt D. was worried since her daughter didn't come home after she received a letter stating her daughter left school, Miss B. wanted to go with Aunt D. to help her find her. I saw Miss B. as someone who cared a great deal for Aunt D. Miss B. also let Peola know how disappointed she was in her by the way she was treating her mother.

The confusion lies here. Being that this is a class on African Americans, I am not sure if I am not looking, or should be looking for hidden reasons (as far as color goes). Because Aunt D. did not move out and buy her own house after she came into some money, am I to think this had anything to do with color? See, I believe it does not. I myself am someone who enjoys taking care of others. It has always been a part of my nature. Did Aunt D. stay because this too was a part of her nature or because since she was black she felt she would not be in her "place" if she did not stay and take care of Miss B. and her daughter? Perhaps this was not a color issue. Just wondering.

The confusion, the hesitancy, the quotation marks as qualifiers suggest that the student has learned that "an honest to goodness" response is not to be trusted, that what comes naturally to her may implicate her in racist language, if not racist social practices. But the language also reveals a strong desire to believe in her natural self, to assure herself that her desires belong to her and are "not a color issue."

In contrast, another woman, who was more than willing to share her response, shows that she has clearly learned the lesson of cultural criticism:

The characteristics given to Delilah were many of the same characteristics attributed to the mammy ste- reotype. All of her tendencies were described as being "natural." For example, Delilah said that it was "natural" for her to raise children. This idea goes back to the notion that mammies have an overwhelming maternal instinct. It was also interesting to see how Delilah was made to be asexual or not involved in any sort of sexual relationship. Even though she at least had one intimate encounter [because she has a child], there was never any interest in her finding a man or love yet she was continually encouraging Mrs. Pullman to fall in love. In other words, Delilah's instincts were maternal not sexual.

It was interesting to see how they portrayed Delilah as being the faithful servant. This stereotype, made up by white America, helps defend the ideology that African-Americans are perfectly satisfied in their subservient position. This is apparent when Mrs. Pullman tells Delilah that she could stop working and be fairly well off but Delilah cannot bear the thought of not taking care of Mrs. Pullman. We are to assume that Delilah cannot live independently of a white person. This was important because it made the audience more comfortable with the relationship between Delilah and Mrs. Pullman. This reassured them that Mrs. Pullman was not taking advantage of Delilah.

This woman displays no anxieties in part because her position in relation to the material she is writing about is not an issue for her. The first woman risks putting herself into the text, as students in women's studies and African American studies are often encouraged to do, and as a result feels like a fraud. The second woman blows the cover, as it were, on the first's comments, showing that those "natural" responses are "ready-made reflections which promise a false identity" (Lydon 248).

Yet however much these journal responses offer conflicting ways of reading the place of the "natural" in our concepts of the subject, the two women hold similar notions of themselves as writing subjects. The first wants desperately to believe in her authenticity and her authority to speak; the second simply assumes these. Indeed, although the second has mastered better than the first the lesson of reading and writing as taught in critical pedagogy, it was the first who came to change her notion of her self as a subject through her writing in the course. For as her rhetoric so painfully reveals, she had implicated herself in what she had written and, as a result, had undermined the authenticity of the I. 
I am not saying that the first student was the better reader because she put herself into the text. The second read with more sophistication at this point in the course. But I am saying that the first at least came to experience through the act of writing itself the kind of self-displacement that so many writers on critical pedagogy advocate. In other words, there is more than one way of getting it right, or wrong. While intellectually and politically astute, the second student's argument makes no demands on her subjectivity. While the first reader sought, and failed, to suppress her whiteness, which emerged through her writing as a category of analysis, the second implicitly suggests through her response that she can and must disavow her whiteness in analyzing whiteness as a racialized identity, thereby reinforcing the notion that knowing can be separated from experience. ${ }^{13}$

\section{Changing the Subject}

Now I'm loud.... This is why I usually get along with African Americans. I mean, when we're together, "Whooo!" It's like I feel totally myself-we just let everything go!

Camille Paglia (qtd. in hooks, Outlaw Culture)

Few white women have so repeatedly attracted charges of passing as has Fannie Hurst over some sixty years of criticism. What made Hurst's representation of black women so controversial, sparking a lengthy debate in Opportunity magazine in the 1930s, was that Hurst actively supported black artists, such as Zora Neale Hurston, her secretary for a time. Through her 1933 novel Imitation of Life, Hurst brought politically charged issues of passing and racism to wide public attention. The 1934 film version of the novel was "one of the first screen dramas that linked issues of race, gender, and sexuality" (hooks, Yearning 3-4). Yet the racist representations of Delilah (the mammy) and Peola (the tragic mulatta) and the two characters' relationship to Bea (the mistress) fostered charges that Hurst was a closet racist, that her identity as a liberal was a fraud. Hurst did not help to dispel this view when she responded to Sterling Brown's attack on the film with the patronizing suggestion that blacks should be grateful to her because the film "practically inaugurates into the important medium of the motion- picture a consideration of the Negro as part of the social pattern of American life" (Letter) or when she wrote an editorial speculating on the notion "if I were a Negro" ("Sure Way"). ${ }^{14}$ Not surprisingly, Brown expressed no more gratitude for the white woman's efforts than does bell hooks for Paglia's comment cited above: "Naturally, all black Americans were more than pleased to have Miss Camille give us this vote of confidence, since we live to make it possible for white girls like herself to have a place where they can be totally themselves" (Outlaw Culture 84).

The controversy surrounding Hurst shares with current feminist debates the question of whether white women write about black women to make black women's experiences and desires known to the white public or to become more comfortable with their own racial and gender identity at a time when many are anxious about the insecurity of identity. Partly for this reason, I include Hurst's novel and the 1934 film version in my African American studies course on the Harlem Renaissance and in my women's studies course on the construction of femininity in twentieth-century Anglo-American culture. Written at a time of increasing concern over the numbers of white women entering the workforce and of black women leaving domestic service, especially as live-in help, the novel expresses the kind of ambivalence that attends systemic social change. Working through the complex relations among race, gender, sexuality, and class in this novel can be a disorienting experience, as the first student's response to the film reveals, but it can also provide a way of coming to terms with presentday forms of passing. As in Nella Larsen's 1929 novel Passing, in Imitation of Life passing is the site where the often competing narratives of racial and gender oppression converge with sexuality.

On the one hand, the phenomenal business success of Bea Pullman (who passes as "B. Pullman, business man" [124]) celebrates the mother's escape from domesticity into "a market economy where she can supposedly own her own labor" (Wiegman 309). On the other hand, the novel appeals to nostalgia for the security that the lost mother represents, especially in the way Bea domesticates commercial space, fashioning her waffle houses as wombs, kennels, and safe havens (134, 149, 161, 235-36). At 
the same time that the novel appeals in the character of Delilah to "racial nostalgia" (Berlant 122) for the lost mammy, it gives Delilah some of the most explicit comments on the operations of race and racism in American society. But the novel's great interest to me is that it makes clear (as the two film versions do not) that at times of increased anxiety over women's changing roles and identities, such as Hurst's depression era or our postmodern moment, the need to return women to the (maternal) body becomes all the more urgent.

What is offbeat about Hurst's novel is that the maternal, traditionally assumed to be woman's natural role, is exposed as a cover for racism and sexism in American society precisely because the maternal is linked with the inability to pass. Like the 1934 film, Hurst's novel ostensibly suggests that racism can be overcome if women band together on the basis of their shared condition of motherhood. As the second student understood, this proposed bond sentimentalizes racist social practices. But while the film's sentimental ending invites such a reading, the novel explodes it.

In the novel, the maternal is revealed to inhibit passing when we find out that Peola, who passes as white and marries a white man, has had herself sterilized (a scene not in the films). To pass, she must reject the possibility of motherhood (giving birth to a dark-skinned child would expose her as a fraud), just as she must demand that her dark-skinned mother, Delilah, "unborn," or disown, her own child. One cannot pass as a mother. This lesson is reinforced at the end of the novel (not in the films) when Bea, whose business success has been driven by a desperate need for domestic security, is deprived of the home she has spent a lifetime dreaming about, planning, building, and furnishing. The home is now occupied by her daughter, who has married the only man Bea ever loved, her business manager eight years her junior, Frank Flake. This cruel punishment for the working mother may make the novel seem complicit with a patriarchal agenda, but the interdependence of the racial and maternal discourses suggests a different reading.

Unlike both screen versions, where Peola returns home at the end to throw herself on her mother's coffin, the novel resists this nostalgia for the imaginary maternal. In the novel, Peola passes completely in Bolivia with her white husband, and the focus at Delilah's Harlem funeral is on Frank's discomfort in the presence of so many black people. "Didn't know there were so many in the world," he says. "There can't be any darkies left anywhere." "Except one," the narrator notes in a parenthetical aside. "In her white man's jungle" (329). This reference to Peola (one of the few narrative intrusions in the novel) reminds us that the plotlines of passing and of the maternal are chiasmatically linked. Bea too is living in the white man's jungle, the world of business. Peola's disappearance from the novel leaves open the possibility that she has successfully disrupted cultural identities and identifications and has thereby elided the effects of race on social relationships and personal identity, a possibility threatening to a racialized society (and hence to Hollywood, which must have Peola return home to reclaim her racial identity). But the subversiveness of the novel actually turns on Peola's sterilization and the link between passing and motherhood. For if Bea is punished at the end and Peola is not, it is because Bea has tried to pass as a mother. Although Peola's sterilization may imply that passing is unnatural, that a black woman passing as white can never do more than impersonate white womanhood, it also allows female desire to be detached from maternal desire, suggesting that the cultural production of femininity can proceed apart from the reproduction of mothering and of mammies and thereby undermine the "natural" basis of female identity (Poovey, "Abortion" 243), as well as the basis for female bonding across racial differences.

Hurst lets the black woman pass, which could, as Sterling Brown charges, reinforce the myth that all blacks want to be white. Yet the representations that Brown uses to argue that Hurst's novel is racistand it is, in more ways than Brown imagined-also locate racism in the cultural production of femininity rooted in the maternal. The first student revealed the same connection, however unwittingly, when not just her whiteness but her femaleness implicated her in a racialized identity: "I myself am someone who enjoys taking care of others. It has always been part of my nature. ... Perhaps this was not a color issue." Hurst's novel suggests that idealizing the maternal is one way white patriarchal culture disavows the threat posed by passing women and that 
in the psychoanalytic narrative of subjectivity, the racialization of the maternal may be more pervasive than the occlusion of women within the symbolic register. It is not a feminist project, Hurst suggests, to reclaim either the maternal or the black woman's body. You have to let it pass.

\section{Let It Pass}

LOUIS. I'm not racist. Well, maybe I am.

BELIZE. Oh, Louis, it's no fun picking on you; you're so guilty.

Chicago production of Angels in America

Writing on the film Imitation of Life, the first student experienced the precariousness of identity that characterizes our postmodern moment. In the end, taking a position on the subject had less farreaching consequences for her writing than did changing her own subject position, for her doubts and hesitations meant that she could no longer take for granted her self as referent. She learned through her writing that the subject position from which one speaks and writes is never secure. Having no secure position to which to return is precisely what distinguishes passing without the as from passing as. Coming to terms with the precariousness of one's own identity opens up the possibility of passing, or, in Toni Morrison's words, of "becoming," the "process of entering what one is estranged from" (4) - which may not be those labeled other but the self that one has long thought one's own. Through her halting efforts to come to terms with gender identity as racially inflected, the first student came to work through (in both senses of that phrase) her own identifications in a way that the second woman, however savvy her response, was never able to do in her writing. The second woman found a secure position from which to write; the first wrote through some precarious positions, a performative process that provided an experience of subjectivity as passing that the second woman's discourse rhetorically suppressed.

The point of all this for the teaching of literature is that we need to provide our students with strategies and occasions for working through rather than taking up-taking a stand on-subject positions. Such opportunities are especially important when- ever we make whiteness visible as a racial category, available for critique and open to delegitimation; whenever we reconceive concepts of essence and experience in the aftermath of poststructuralist theories; and whenever we engage the politics of identity in postmodernity and in cultural criticism. ${ }^{15}$ The double bind created by the discrepancy between what we profess and how we are positioned, between the demands of a critical pedagogy and the constraints of postmodern culture, cannot be resolved only in theory but must also be confronted performatively in the literature classroom. My readings of the critical essays, the student responses, and the novel are intended to alert us to those moments when passing is happening in our classrooms and our writing so that we can exploit the analytical, political, and ethical possibilities it creates.

It is not that I would reject self-critique by whites writing on race or men writing on feminism. On the contrary. But I would argue that self-critique can be effective only when we do not attempt to reclaim the body, to revive the humanist subject, or to find appropriate figures for postmodern subjectivity. Self-critique without a postmodernist effort to free concepts of identity from their metaphysical foundations leaves only a choice between the confessional and the fraudulent. The problem is not self-critique: it is rather, as Mary Poovey writes in another context ("Feminism," esp. 38), that the humanist subject continues to be produced as a solution to the cultural problematic that places us all in the position of passing. The more passing becomes the possibility opened up by our interrogation of subject positions, the more, it seems, we defend ourselves against it by making it unnatural or illegitimate. Such a cultural problematic, however, cannot be elided by any I seeking a more authentic position. We cannot get out of passing by attempting to reclaim the subject, the body, or the real thing. We have to let it pass.

\section{Notes}

I wish to thank the following friends and colleagues for their helpful comments on this essay: Anne Callahan, Susan Cavallo, 
Judy Massey Dozier, Susan Jarratt, Eleanor Honig Skoller, Isaiah Smithson, and Lynn Worsham. Thanks also go to Michele Troy for her editorial assistance and to Danielle Glassmeyer for her research on Hurst.

'I borrow the term culture studies from Isaiah Smithson, who attributes it to Gayatri Spivak. As opposed to cultural studies, culture studies designates less a distinct methodology and critical tradition than the state of the humanities in the aftermath of the theoretical and social upheavals of the past two decades. See Smithson for a brief but detailed definition of culture studies. I use cultural critics to refer not just to practitioners of cultural studies and to critics of popular culture but also to scholars and teachers whose object of study is the effect, not the origin, of representations and discourses and who see their task as one of "interrogating cultural phenomena rather than elucidating literary masterpieces" (Smithson 1).

Originally I intended the subtitle of my essay to allude to a 1985 paper by Nancy K. Miller, "Changing the Subject: Authorship, Writing, and the Reader" (ch. 5 in her Subject to Change), which argues that a poststructuralist concept of the subject does not work for women. But I have since found this phrase in other relevant works. Changing the Subject is a 1984 collection of essays that integrates psychoanalytic theories of subjectivity with a Foucauldian concern for the social discourses and technologies that regulate subjectivity (Henriques et al.). In "On the Subjects of Class and Gender in 'The Literacy Letters," Linda Brodkey uses the phrase as the subtitle of a section on postmodern theories of subjectivity. Gayle Greene and Coppélia Kahn gave the title Changing Subjects: The Making of Feminist Literary Criticism to a 1993 collection they edited, which historicizes and theorizes the personal to reclaim for feminists the legitimacy of saying "I" and "we." "Changing the subject" seems to be a defining trope for feminism in the wake of poststructuralism.

${ }^{2}$ In my text, I use the first-person plural pronoun ethically, to implicate my readers in a cultural problematic that requires a shared structure of response. I differentiate between the we of performative engagement and the we of disembodied truth. In a performative practice, we refers not to discrete identities that exist before engagement with others but to identities brought into beirig through engagement. While feminist and African American critics have rightly questioned the imperial we in writing that takes white male experience as the norm, now critics by no means marginalized can mobilize that resistance to the use of we in their own interests, to escape their implication in the structural dynamics that I call passing. But the issue is more complicated even than that. It would be too easy to distinguish absolutely between the imperial we and the performative we; such a distinction ignores the inevitable slippage between the two, which is the subject of this article.

${ }^{3}$ On the issue of who can speak in the classroom, see, e.g., Fuss, Speaking, esp. the last chapter, "Essentialism in the Classroom"; hooks, Teaching, esp. the critique of Fuss in ch. 6, and Yearning.

4. "Postmodern culture" is a shorthand to refer to a number of social, cultural, economic, and technological changes over the past three decades that have converged to alter profoundly our experience of and our thinking about identity in Western culture.
These changes are registered, in Poovey's words, "as challenges to the most basic units of humanist understanding - the individuality of the subject and the bodily integrity of the person" ("Feminism" 39).

${ }^{5}$ On the characterization of passing as betrayal in classic passing texts, see V. Smith.

${ }^{6}$ Trying to mediate between humanism's autonomous subject and poststructuralism's depersonalized subject, Alcoff's concept of positionality defines the subject by social location and historical experiences rather than by essential attributes. Positionality conceives the subject's position as "a place from where meaning is constructed, rather than simply the place where a meaning can be discovered (the meaning of femaleness)" ("Feminism" 434).

${ }^{7} \mathrm{My}$ critique of arguments like Alcoff's that are based on a notion of positionality is meant not to deny that subjects are positioned but to undercut the idea that one acts from a fixed or prior position. The kind of self-critique Alcoff advocates, where one identifies oneself by race, gender, sexuality, class, age, and so on, before speaking, assumes that the subject is positioned before speaking. In a performative view, the subject is brought into being through the engagement with others. Judith Butler in "For a Careful Reading" and Phillip Brian Harper in "The Subversive Edge" " correct common misreadings of performativity that assume a subject acts voluntarily, taking on a certain subjectivity as if playing a role. This voluntaristic I is not the subject that informs my conception of passing.

${ }^{8}$ As Susan David Bernstein says, "Any rhetorical posture, whether in an article or in the classroom, is already mediated, compromised by desires, by forces of language and culture, that cannot be grasped together by any one 'I.'" The subject is not reduced to its linguistic performance, she adds, but "the dimensions of language structure the representation of any epistemological claims about an 'I'"' $(127,142)$. Alcoff tries both to acknowledge and, in the interests of a coalition politics, to obviate the truth of this deconstruction of the I. In contrast, my passing is an effort to work through the radical implications of Derrida's practice, as do Judith Butler (Bodies and "Reading") and Drucilla Cornell (Accommodation and Philosophy). Whereas coalition politics makes the erroneous assumption that to surrender categories of identity is to surrender politics, Butler seeks to articulate a politics that is not tied to identity categories. In the dynamics of passing, one cannot worry about being exposed as either the real thing or a fraud, for passing contaminates the distinction between the two. Passing delimits positionality but in doing so no more abandons the notion of position than Derrida's "iterability"- the principle that any sign is necessarily a repetition or citation, which limits intentionality's role in the determination of meaning - abandons the category of intentionality.

${ }^{9}$ The psychological no less than the political is historical (Willis 320). Susan Standford Friedman uses the term "psycho/ political dynamics" in an essay that attempts to negotiate between poststructuralist and nonpoststructuralist feminisms, especially between their conflicting notions of the subject (474).

${ }^{10} \mathrm{I}$ argue in the introduction to my book Passing and Pedagogy that many performance artists get it right-that is, they understand the performativity of subjectivity that academics may concede in theory but often forget in practice. 


\begin{abstract}
${ }^{11}$ The term critical pedagogy, referring to activist teaching in general, designates a practice that necessarily concerns itself with questions of subjectivity and agency in postmodern culture. See, for example, Aronowitz and Giroux 117-18; Giroux; George and Shoos 201-02; Jarratt 107-17. My reading of Homans and Abel, like their readings of feminists, seeks to understand the complex and contradictory positions writers and teachers inhabit in cultural criticism and in postmodern culture. I write on these essays not to refute them but to discover by working through them what I can say and do, what positions I can and cannot assume as a feminist critic and teacher.

${ }^{12}$ Poovey analyzes various defenses against the pervasive fear that the nature of the human is at risk in postmodern culture ("Feminism" 35-36). I borrow from her description to account for how postmodernist feminist theory prompts defensive responses in some feminists afraid that it eliminates the body. On the notion of identity at risk in postmodern culture, see Poovey, "Feminism"; Butler, Bodies and "Imitation"; and Wicke.

${ }^{13}$ On this notion, see Harding.

${ }^{14}$ Hurst passed in other ways. To experience lives she wrote about, she would engage in impersonation. Once she took a job as a shopgirl in her father's factory so that she could portray such a lifestyle in a novel. To create a place for her, Hurst's father fired the real thing. This example should be enough to warn us against the dangers of overgeneralizing about the ethics of passing. "There is passing and then there is passing" (Butler, Bodies 130).

${ }^{15}$ On the problems that can arise in the classroom whenever we interrogate whiteness and other racialized identities, see Keating, especially her observation that students often conflate representations of whiteness with white people.
\end{abstract}

\section{Works Cited}

Abel, Elizabeth. "Black Writing, White Reading: Race and the Politics of Feminist Interpretation." Critical Inquiry 19 (1993): 470-98.

Alcoff, Linda. "Cultural Feminism versus Post-structuralism: The Identity Crisis in Feminist Theory." Signs 13 (1988): 405-36. - "The Problem of Speaking for Others." Cultural Critique 20 (1991-92): 5-32.

Aronowitz, Stanley, and Henry A. Giroux. Postmodern Education: Politics, Culture, and Social Criticism. Minneapolis: U of Minnesota P, 1991.

Bathrick, David. "Cultural Studies." Introduction to Scholarship in Modern Languages and Literatures. Ed. Joseph Gibaldi. New York: MLA, 1992. 320-40.

Berlant, Lauren. "National Brands / National Bodies: Imitation of Life." Comparative American Identities: Race, Sex, and Nationality in the Modern Text. Ed. Hortense J. Spillers. New York: Routledge, 1991. 110-40.

Bernstein, Susan David. "Confessing Feminist Theory: What's 'I' Got to Do with It?" Hypatia 7.2 (1992): 120-47.

Brodkey, Linda. "On the Subjects of Class and Gender in 'The Literacy Letters."” College English 51 (1989): 125-41.
_- "Postmodern Pedagogy for Progressive Educators." Journal of Education 169.3 (1987): 138-43.

Brown, Sterling A. "Imitation of Life: Once a Pancake." Opportunity: A Journal of Negro Life Mar. 1935: 87-88.

Butler, Judith. Bodies That Matter: On the Discursive Limits of Sex. New York: Routledge, 1993.

-. "For a Careful Reading." Feminist Contentions: A Philosophical Exchange. Ed. Seyla Benhabib et al. New York: Routledge, 1995. 127-43.

- Gender Trouble: Feminism and the Subversion of Identity. New York: Routledge, 1990.

_. "Imitation and Gender Insubordination." Inside/Out: Lesbian Theories and Gay Theories. Ed. Diana Fuss. New York: Routledge, 1991. 13-31.

Carby, Hazel V. Reconstructing Womanhood: The Emergence of the Afro-American Woman Novelist. New York: Oxford, 1987.

Caughie, Pamela L. Passing and Pedagogy: The Dynamics of Responsibility. Urbana: $\mathrm{U}$ of Illinois $\mathrm{P}$, forthcoming.

Cornell, Drucilla. Beyond Accommodation: Ethical Feminism, Deconstruction, and the Law. New York: Routledge, 1991.

-The Philosophy of the Limit. New York: Routledge, 1992.

Crowley, Sharon. A Teacher's Guide to Deconstruction. Urbana: NCTE, 1989.

Derrida, Jacques. Limited Inc. Evanston: Northwestern UP, 1988.

Europa, Europa. Dir. Agnieszka Holland. CCC Filmkunst; Les Films de Losange, 1991.

Faigley, Lester. Fragments of Rationality: Postmodernity and the Subject of Composition. Pittsburgh: $\mathrm{U}$ of Pittsburgh P, 1992.

Friedman, Susan Standford. "Post/Poststructuralist Feminist Criticism: The Politics of Recuperation and Negotiation." New Literary History 22 (1991): 465-90.

Fuss, Diana. Essentially Speaking: Feminism, Nature, and Difference. New York: Routledge, 1989.

George, Diana, and Diana Shoos. "Issues of Subjectivity and Resistance: Cultural Studies in the Composition Classroom." Cultural Studies in the English Classroom. Ed. James A. Berlin and Michael J. Vivion. Portsmouth: Boynton, 1992. 200-10.

Giroux, Henry A. "Resisting Difference: Cultural Studies and the Discourse of Critical Pedagogy." Grossberg, Nelson, and Treichler 199-212.

Greene, Gayle, and Coppélia Kahn, eds. Changing Subjects: The Making of Feminist Literary Criticism. New York: Routledge, 1993.

Grossberg, Lawrence, Cary Nelson, and Paula A. Treichler, eds. Cultural Studies. New York: Routledge, 1992.

Harding, Sandra. "Who Knows? Identities and Feminist Epistemology." (En)Gendering Knowledge. Ed. Joan E. Hartman and Ellen Messer-Davidow. Knoxville: U of Tennessee P, 1991. 100-20.

Harper, Phillip Brian. Framing the Margins: The Social Logic of Postmodern Culture. New York: Oxford, 1994.

- " "The Subversive Edge': Paris Is Burning, Social Critique, and the Limits of Subjective Agency." Diacritics 24.2-3 (1994): 90-103. 
Henriques, Julian, et al. Changing the Subject: Psychology, Social Regulation, and Subjectivity. New York: Methuen, 1984.

Homans, Margaret. "'Women of Color' Writers and Feminist Theory." New Literary History 25 (1994): 73-94.

hooks, bell. Outlaw Culture: Resisting Representations. New York: Routledge, 1994.

. Talking Back: Thinking Feminist, Thinking Black. Boston: South End, 1989.

- Teaching to Transgress: Education as the Practice of Freedom. New York: Routledge, 1994.

- Yearning: Race, Gender, and Cultural Politics. Boston: South End, 1990.

Hurst, Fannie. Imitation of Life. New York: Collier, 1993. - Letter. Opportunity: A Journal of Negro Life 13 Apr. 1935: 121

."The Sure Way to Equality." Negro Digest June 1946: 27-28. Imitation of Life. Dir. John Stahl. Universal, 1934.

Jarratt, Susan C. Rereading the Sophists: Classical Rhetoric Refigured. Carbondale: Southern Illinois UP, 1991.

Keating, AnnLouise. "Interrogating 'Whiteness,' (De)Constructing Race." College English 57 (1995): 901-18.

Larsen, Nella. Passing. New York: Knopf, 1929.

Lydon, Mary. Skirting the Issue: Essays in Literary Theory. Madison: U of Wisconsin P, 1995.

McClary, Susan. Feminine Endings: Music, Gender, and Sexuality. Minneapolis: U of Minnesota P, 1991.

Miller, Nancy K. "Criticizing Feminist Criticism." Conflicts in Feminism. Ed. Marianne Hirsch and Evelyn Fox Keller. New York: Routledge, 1990. 349-69.

Subject to Change: Reading Feminist Writing. New York: Columbia UP, 1988.

Morrison, Toni. Playing in the Dark: Whiteness and the Literary Imagination. Cambridge: Harvard UP, 1992.

Nelson, Cary, Paula A. Treichler, and Lawrence Grossberg. "Cultural Studies: An Introduction." Grossberg, Nelson, and Treichler 1-16.
Poovey, Mary. "The Abortion Question and the Death of Man." Feminists Theorize the Political. Ed. Judith Butler and Joan W. Scott. New York: Routledge, 1992. 239-56.

. "Cultural Criticism: Past and Present." College English 52 (1990): 615-25.

- "Feminism and Postmodernism: Another View." Boundary 2 19.2 (1992): 34-52.

Robinson, Amy. "It Takes One to Know One: Passing and Communities of Common Interest." Critical Inquiry 20 (1994): 715-36.

Smith, Paul. Discerning the Subject. Minneapolis: U of Minnesota $\mathrm{P}, 1988$.

Smith, Valerie. "Reading the Intersection of Race and Gender in Narratives of Passing." Diacritics 24.2-3 (1994): 43-57.

Smithson, Isaiah. Introduction. English Studies / Culture Studies. Ed. Smithson and Nancy Ruff. Urbana: U of Illinois P, 1994. 1-22.

Suleiman, Susan Rubin. Risking Who One Is: Encounters with Contemporary Art and Literature. Cambridge: Harvard UP, 1994.

Wicke, Jennifer. "Postmodern Identities and the Politics of the (Legal) Subject." Boundary 2 19.2 (1992): 10-33.

Wiegman, Robyn. "Black Bodies / American Commodities: Gender, Race, and the Bourgeois Ideal in Contemporary Film." Unspeakable Images: Ethnicity and the American Cinema. Ed. Lester D. Friedman. Urbana: U of Illinois P, 1991. 308-28.

Willis, Susan. "Eruptions of Funk: Historicizing Toni Morrison." Toni Morrison: Critical Perspectives Past and Present. Ed. Henry Louis Gates, Jr., and K. A. Appiah. New York: Amistad, 1993. 308-29.

Zavarzadeh, Mas'ud, and Donald Morton. "Theory Pedagogy Politics: The Crisis of 'the Subject' in the Humanities." Theory/Pedagogy/Politics: Texts for Change. Ed. Morton and Zavarzadeh. Urbana: U of Illinois P, 1991. 1-32. 